\title{
Assessment of water quality and suitability analysis of River Ganga in Rishikesh, India
}

\author{
A. K. Haritash $\cdot$ Shalini Gaur $\cdot$ Sakshi Garg
}

Received: 27 September 2013 / Accepted: 25 September 2014/Published online: 12 October 2014

(C) The Author(s) 2014. This article is published with open access at Springerlink.com

\begin{abstract}
The water samples were collected from River Ganga in Rishikesh during December 2008 to assess its suitability for drinking, irrigation, and industrial usages using various indices. Based on the values obtained and suggested designated best use, water in upper segment can be used for drinking but after disinfection (Class A); organized outdoor bathing in middle segment (Class B); and can be used as drinking water source (Class C) in lower segment in Rishikesh. All the parameters were within the specified limits for drinking water quality except $E$. coli. The indices of suitability for irrigation and industrial application were also evaluated. The irrigation quality ranged from good to excellent at almost all places with the exception of percent sodium. The abundance of major ions followed $\mathrm{K}^{+}>\mathrm{Ca}^{2+}>\mathrm{Cl}^{-}>\mathrm{HCO}_{3}^{-}>\mathrm{Na}^{+}>\mathrm{Mg}^{2+}>$ $\mathrm{CO}_{3}{ }^{2-}$ trend. The major cations suggested that the water is alkaline $(\mathrm{Na}+\mathrm{K})$ than alkaline earth $(\mathrm{Ca}+\mathrm{Mg})$ type. The heavy metals $(\mathrm{Pb}, \mathrm{Cu}, \mathrm{Zn}, \mathrm{Ni})$ were found either absent or within the limits specified. There was no specific industrial input of pollutants. Industrial applications of the river water should be limited since the water was found to be aggressive, based on Langelier saturation index (0.3) and Ryznar stability index (8.8), with the problem of heavy to intolerable corrosion. Water quality of Ganga in Rishikesh was good with exception of most probable number (MPN) which needs regular monitoring and measures to control.
\end{abstract}

Electronic supplementary material The online version of this article (doi:10.1007/s13201-014-0235-1) contains supplementary material, which is available to authorized users.

A. K. Haritash $(\bowtie) \cdot$ S. Gaur $\cdot$ S. Garg

Department of Environmental Engineering, Delhi Technological

University, Bawana Road, Shahbad, Delhi 110042, India

e-mail: akharitash@dce.ac.in
Keywords Ganga - Designated best use (DBU) .

Rishikesh · Residual sodium carbonate (RSC) · Sodium adsorption ratio (SAR) · Permeability index (PI) · Langelier saturation index (LSI)

\section{Introduction}

Ganga River originates from Gangotri glacier situated between $30^{\circ} 43^{\prime} 22^{\prime \prime} 30^{\circ} 50^{\prime} 49^{\prime \prime}$ North latitude and $79^{\circ} 4^{\prime} 4^{\prime \prime}-$ $79^{\circ} 16^{\prime} 34^{\prime \prime}$ East longitude, about 4,100 m above mean sea level. It is a valley-type glacier with a length of $30.20 \mathrm{~km}$, and width varying from 0.5 to $2.5 \mathrm{~km}$ (NRCD 2009) situated in the Uttarkashi district of Garhwal Himalaya. Ganga river basin is the largest among river basins in India and the fourth largest in the world, with a catchment area of 8,61, $404 \mathrm{sq} \mathrm{km}$. and a total length of $2,525 \mathrm{~km}$. It is one of the most densely populated river basins in the world, supporting 29 Class-I cities (population $\geq 100,000$ ), 23 ClassII cities (population 50,000-99,999), 48 towns, and thousands of villages. Over 500 million people were estimated to be living in the entire Ganga river basin in 2000, and this number is expected to grow to over 1 billion by 2030 (Markandya and Murty 2004). Nearly all the sewage from these cities enters the basin waterways partially treated or untreated, totalling 1.3 billion litres per day of human waste, and 260 million liters of industrial waste, primarily from agricultural fertilizers and pesticides (Markandya and Murty 2004). In addition to these domestic and industrial pollutants, hundreds of human corpses and thousands of animal carcasses are released to the river each day for spiritual rebirth. Studies have reported that waste discharge exceeded available river water in the state of Uttar Pradesh, just prior to the yearly monsoon (Lacy 2006; Vass et al. 2010). Population pressures, lack of proper investment in 
water quality infrastructure, limited governmental initiatives, and a lack of empowerment of the people all continue to contribute to the deteriorating state of the Ganga (Mishra and Tripathi 2008; Rai et al. 2010). Till date, there have been various studies on river water quality with reference to geochemistry and pollution (NRCD 2008, 2009; Li et al. 2009; Li and Zhang, 2010; Trivedi 2010; Seth et al. 2013), and suitability assessment of groundwater for different uses (Kaushik et al. 2000; Haritash et al. 2008; Srinivas et al. 2013; Sivasubramanian et al. 2013). The water from River Ganga is used for irrigation primarily; and as a source for drinking water and industrial applications. It, therefore, becomes imperative to assess the suitability of water for different uses. The present study has been undertaken to assess the water quality of Ganga in Rishikesh town and its suitability for drinking, agricultural, and industrial use.

Rishikesh, surrounded by virgin forests at the toe of the Himalayas, is the first town on River Ganga taken up under the Ganga Action Plan (GAP) Phase-I for pollution abatement of the river. The GAP works in Rishikesh comprise sewerage works to tap the sewage outfalls through appropriate pumping station, and diversion of the sewage to a pond type STP at Lakkarghat between Haridwar and Rishikesh. Still hundreds of ashrams, temples, residences, hotels and other commercial establishments dot the banks and this immense human activity, in a narrow band along the length of the town on both the banks, generates millions of litres of sewage per day into river Ganga. Rishikesh, unlike other cities, is the first pilgrimage-cum-tourist destination after the river enters plains, and upstream-located industrial/anthropogenic sources of pollution which may affect the water quality are absent. Any addition upstream of Rishikesh may be treated as natural. Since natural flow of water in winters is lean; and tourist activity during December (Christmas and New Year) is more, it may affect water quality adversely particularly during this period. The present study was, therefore, carried out in December to study the designated best use of water, and its suitability for different usages based on various indices of water quality.

\section{Materials and methods}

The study was carried out in Rishikesh town of Uttaranchal state. A total of 20 samples were collected along the banks of River Ganga from Mini Goa Beach (upstream of Rishikesh) to Bhardwaj Sthal (Downstream of Rishikesh) in December 2008. Sampling locations (Fig. 1) were identified on the basis of prominent activities of bathing, washing, addition of sewage/wastewater into the river. Bulk samples were collected from a distance at least five feet inside from the banks in pre-rinsed sterilized plastic bottles. The $\mathrm{pH}$, electrical conductivity (EC), total dissolved solids (TDS), temperature, and salinity (as $\mathrm{NaCl}$ ) were analysed on the site using HACH (USA) made HQ40-D-Multi model meter (Hossain et al. 2010). Dissolved oxygen (DO) was also analysed on the site using DO probe fitted with $\mathrm{HACH}$ made HQ30-D-Flexi model meter. The samples were stored at $5{ }^{\circ} \mathrm{C}$ in an ice box, transported to the laboratory and analysed for other parameters within $6 \mathrm{~h}$ using standard methods of APHA (Eaton et al. 1995). Fluoride $\left(\mathrm{F}^{-}\right)$was measured using $\mathrm{F}^{-}$ion electrode fitted with Thermo Orion model 720A20 + meter, and total organic carbon (TOC) was analysed on Analytik-jena Multi N/C-2100 TOC analyzer based on non-dispersive infra-red (NDIR) spectroscopy. Lead $(\mathrm{Pb})$, Copper $(\mathrm{Cu})$, Zinc $(\mathrm{Zn})$, and Nickel $(\mathrm{Ni})$ were analysed on Shimadzu made model AA-6300 atomic absorption spectrophotometer (AAS). In order to assess the suitability for irrigation residual sodium carbonate (RSC), soluble sodium percentage (SSP), sodium adsorption ratio (SAR), permeability index (PI), Kelley's ratio (KR), and magnesium hazard (Mg Haz.) was evaluated.

\begin{tabular}{ll}
\hline $\mathrm{RSC}=\left(\mathrm{HCO}_{3}^{-}+\mathrm{CO}_{3}^{2-}\right)-\left(\mathrm{Ca}^{2+}+\mathrm{Mg}^{2+}\right)$ & $($ Eaton 1950) \\
$\mathrm{SSP}=\left[\mathrm{Na}^{+} /\left(\mathrm{Ca}^{2+}+\mathrm{Mg}^{2+}+\mathrm{Na}^{+}\right)\right] \times 100$ & $($ Eaton 1950) \\
$\mathrm{SAR}=\mathrm{Na}^{+} /\left(\mathrm{Ca}^{2+}+\mathrm{Mg}^{2+} / 2\right)^{1 / 2}$ & $($ Richards \\
$\mathrm{PI}=\left[\mathrm{Na}^{+}+\left(\mathrm{HCO}_{3}^{-}\right)^{1 / 2} /\right.$ & 1954) \\
$\left.\left(\mathrm{Ca}^{2+}+\mathrm{Mg}^{2+}+\mathrm{Na}^{+}\right)\right] \times 100$ & $($ Doneen \\
$\mathrm{KR}=\mathrm{Na}^{+} /\left(\mathrm{Ca}^{2+}+\mathrm{Mg}^{2+}\right)$ & 1962) \\
$\mathrm{Mg}$ Haz. $=\left(\mathrm{Mg}^{2+} \times 100\right) /\left(\mathrm{Ca}^{2+}+\mathrm{Mg}^{2+}\right)$ & $($ Kelly 1963) \\
\hline
\end{tabular}

All ionic concentrations are in milli equivalent per litre (meq/l).

\section{Results and discussion}

\section{Suitability for drinking}

The representative samples collected from the study area were analysed for their physical, chemical, and biological properties for determining their designated best use. The results obtained are given in Table 1. The temperature of water was in the range of 10.2-21.0 with an average of 17.5. Comparatively higher temperatures at places could be attributed to the decreased flow rate or very shallow rocky river bed exposed to direct sunlight raising the temperature of water flowing through/over. So, temperature of the river water was observed to be a function of depth, turbulence, time of the day, and heat input from outer environment. The $\mathrm{pH}$ values of the samples were in the range of 9.0-10.5 with a mean value of 9.4 indicating that the water is 
Fig. 1 Location of sampling sites in Rishikesh town

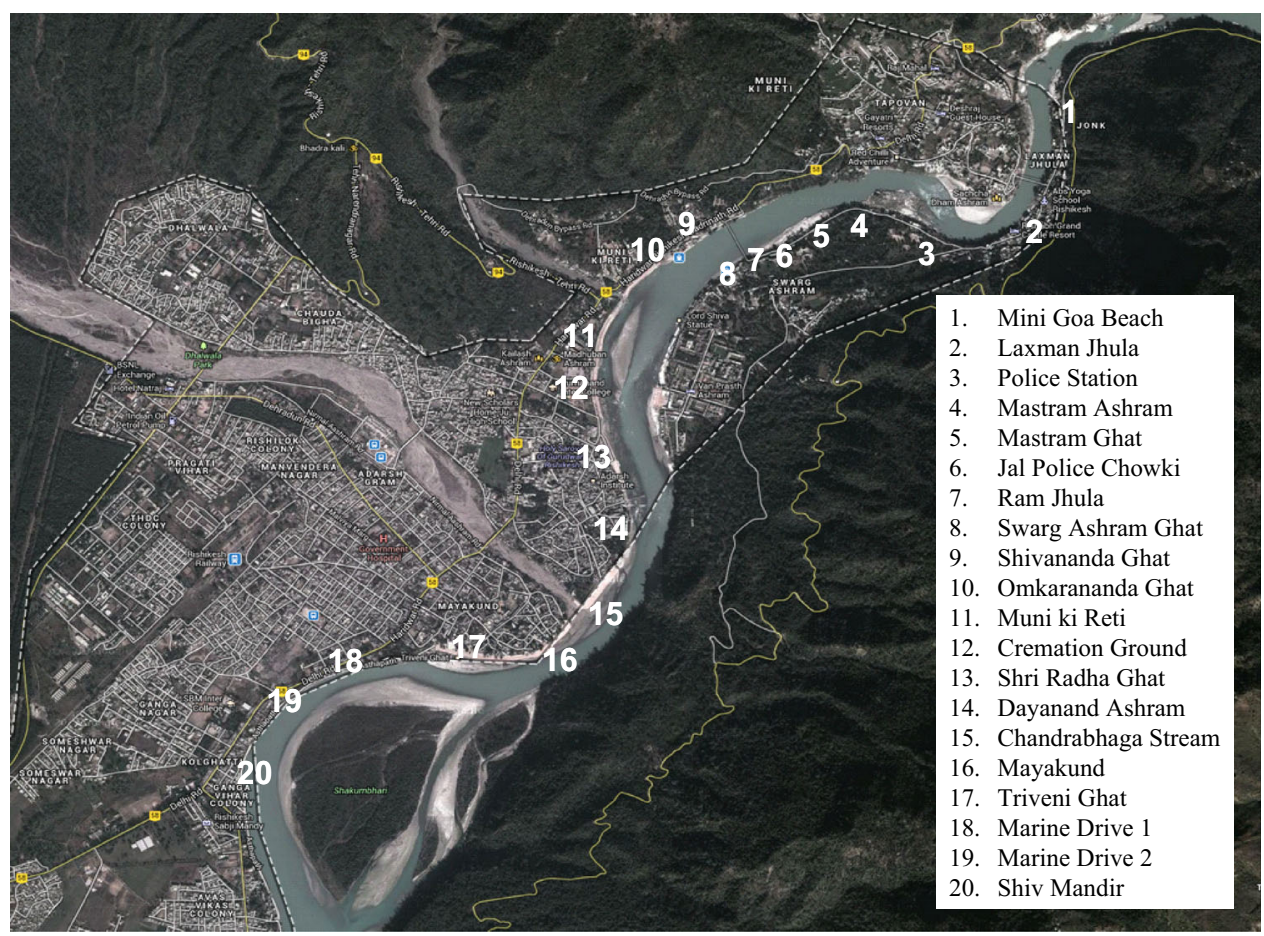

slightly alkaline. Electrical conductivity (EC) represents the concentration of different ions present. EC varied from 38.0 to $170 \mu \mathrm{S} / \mathrm{cm}$ with the mean value of $85.2 \mu \mathrm{S} / \mathrm{cm}$. Comparatively higher values were observed at location \#10 and downstream owing to the external input of wastewater. Still higher values of EC from Dayanand Ashram to Triveni Ghat were a result of addition of sewage from Chandrabhaga stream and wastewater from the ashrams. The TDS ranged from 18.0 to $85.0 \mathrm{mg} / \mathrm{l}$ with an average value of 38.6. Higher values of TDS at location \#11 and 12 may be attributed to addition of sewage and suspension of ashes from cremation ground near the locations. The desirable limit for TDS in drinking water is $500 \mathrm{mg} / \mathrm{l}$. Salinity (expressed as per thousand) ranged from 0.01 to 0.08 with a mean value of 0.04 . Alkalinity of the water exhibited more variation and ranged from 32.0 to $144.0 \mathrm{mg} / \mathrm{l}$ with an average value of $70.4 \mathrm{mg} / \mathrm{l}$. About $90 \%$ of the samples were having bicarbonate as the major species responsible for the alkalinity. As per the Bureau of Indian Standards (BIS) standards (2012) (Table 2), the limit of alkalinity in drinking water is $200 \mathrm{mg} / \mathrm{l}$.

The dissolved oxygen (DO) in water is an important parameter to monitor the biological quality of water, and ascertain its designated best use. It supports the aquatic life forms and regulates the biological degradation of organic impurities. DO level of River Ganga in Rishikesh during December was fairly good with an average of $10.0 \mathrm{mg} / \mathrm{l}$. A slight decrease in DO at location \#11 and at confluence with Chandrabhaga could be attributed to the addition of sewage upstream. It was observed that DO concentration in river water is a function of temperature, turbulence, depth, and organic matter present. The total hardness $(\mathrm{TH})$ in river water is primarily regulated by the carbonates, bicarbonates, chlorides, sulphates, etc. of calcium and magnesium chiefly, whereas there are certain other chemical entities accounting for it. The hardness levels varied from 64.0 to $212.0 \mathrm{mg} / \mathrm{l}$ with a mean value of $101.2 \mathrm{mg} / \mathrm{l}$. The observations revealed that the major source of hardness ions is the wastewater from domestic use. The desirable limit for total hardness in drinking water, as per BIS, India is $300 \mathrm{mg} / \mathrm{l}$. These results revealed that wastewater from domestic use had a fair proportion of calcium bound ions adding to total hardness. The contribution of carbonate and bicarbonate ions towards hardness was analysed and it was observed that carbonate concentration was nil at most of the places except at the locations where a source of wastewater discharge was observed $(4.8 \mathrm{mg} / \mathrm{l})$. The bicarbonate concentration varied from 4.9 to $34.2 \mathrm{mg} / \mathrm{l}$ with a mean value of $18.8 \mathrm{mg} / \mathrm{l}$. The chloride ions $\left(\mathrm{Cl}^{-}\right)$account for the permanent hardness in water. Its concentration varied from 10.0 to $32.5 \mathrm{mg} / \mathrm{l}$ with a mean value of $22.1 \mathrm{mg} / \mathrm{l}$, and lower concentration of chloride ions was observed at upstream locations. The concentration with respect to drinking quality was within the limit $(250 \mathrm{mg} / \mathrm{l})$ specified by BIS.

Phosphate in river water is the limiting factor for eutrophication. Phosphate levels varied from 3.6 to $4.8 \mathrm{mg} / \mathrm{l}$ with a mean value of $4.2 \mathrm{mg} / 1$. Maximum concentration $(4.8 \mathrm{mg} /$ 1) was noticed in the stretch from confluence with Chandrabhaga to Triveni Ghat and it was regulated by the 


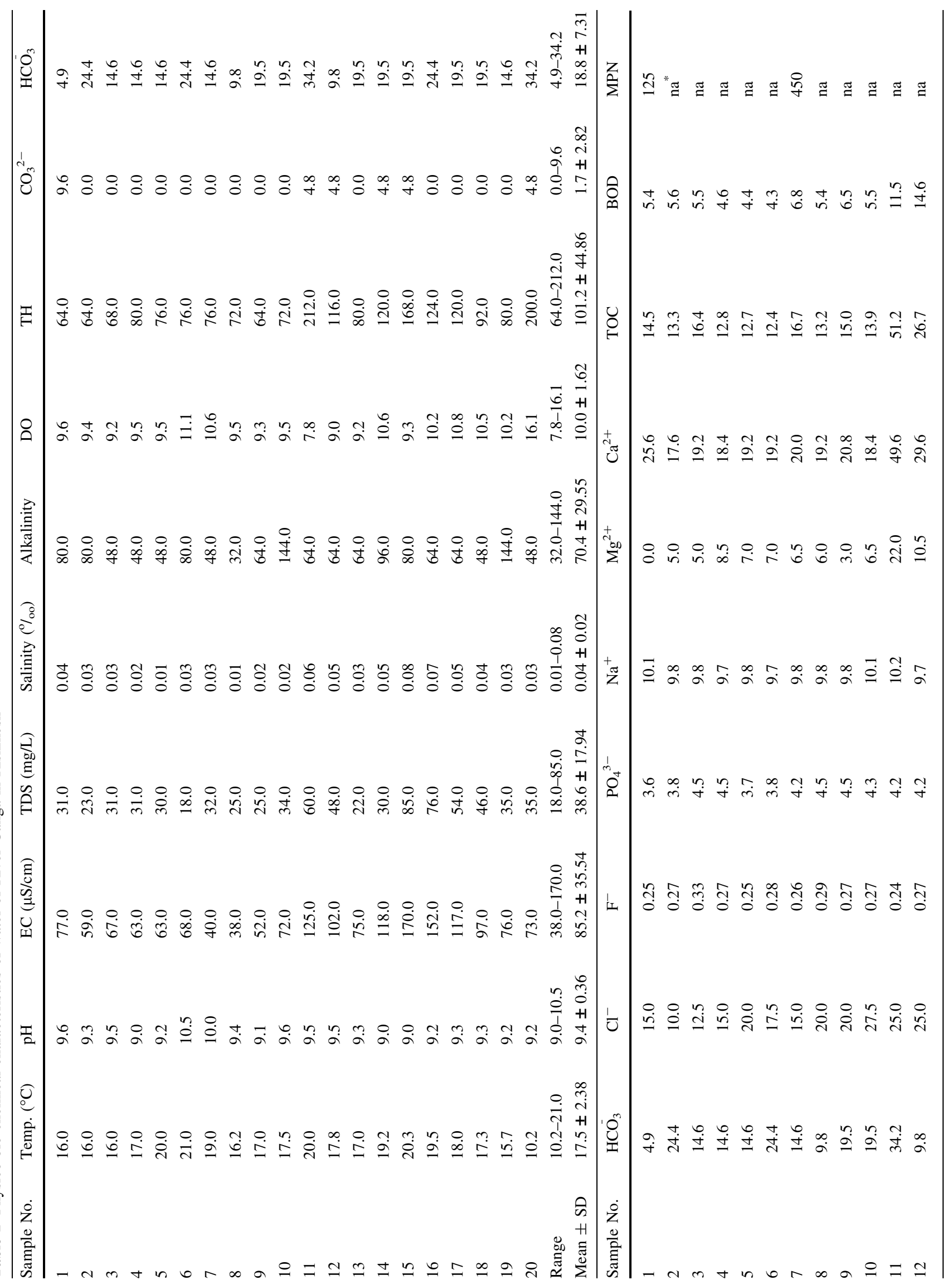




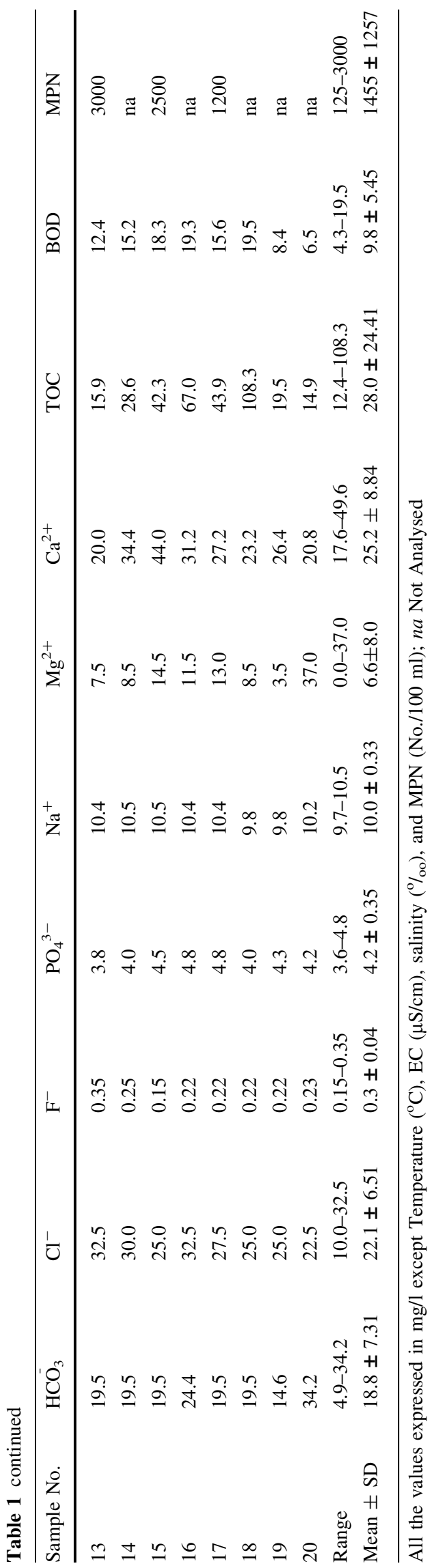

wastewater added by the stream of Chandrabhaga. Fluoride is an important parameter for establishing quality of drinking water. It was found to be fairly lower than the standard limit of $1.0 \mathrm{mg} / \mathrm{l}$ (WHO 2006). The concentration varied from 0.15 to $0.35 \mathrm{mg} / \mathrm{l}$. The sodium $\left(\mathrm{Na}^{+}\right)$concentration varied from 9.7 to $10.7 \mathrm{mg} / \mathrm{l}$ with a mean value of $10.0 \mathrm{mg} / \mathrm{l}$. Lower concentrations were represented at the sampling locations in the first segment (location \#1-10) and higher levels were reported at the locations where a source of discharge was observed (location \#11-17). Similarly, calcium concentration ranged from 17.6 to $49.6 \mathrm{mg} / \mathrm{l}$ with a mean value of $25.2 \mathrm{mg} / \mathrm{l}$. It was found to be well within the limits for drinking as the desirable limit for calcium, as per Indian Standard (BIS 10500: 2012) is $75 \mathrm{mg} / \mathrm{l}$.

In order to measure the organic pollution in Ganga, biological oxygen demand $\left(\mathrm{BOD}_{5}\right)$ and total organic carbon (TOC) were determined. The $\mathrm{BOD}_{5}$ ranged from 4.3 to $19.5 \mathrm{mg} / \mathrm{l}$ with a mean value of $9.8 \mathrm{mg} / \mathrm{l}$. Maximum concentration $(19.5 \mathrm{mg} / \mathrm{l})$ was observed downstream of Triveni Ghat and the probable reason is offerings in the form of milk, flowers, sweets, and addition of wastewater by a thin channel immediately downstream of Triveni ghat. Lower levels were observed in the upper segment. Similarly, TOC values were lower in the upper segment and higher in the lower stretch owing to the sources located in the region. TOC concentration varied from 12.4 to $108.3 \mathrm{mg} / \mathrm{l}$ with a mean value of $28.0 \mathrm{mg} / \mathrm{l}$. Maximum concentration of TOC was reported at location \#18. The most probable number (MPN) was determined at five locations only (S. No. 01, 07, 13, 15, and 17). It was maximum $(3,000 / 100 \mathrm{ml})$ at location $\# 13$ followed by confluence with Chandrabhaga stream (\#15) (2,500/ $100 \mathrm{ml}$ ). The disposal of night soil in river bed in the vicinity of cremation ground; and discharge from Chandrabhaga stream add the E. coli bacteria to the river. It reveals that most of the pollution load in River Ganga in Rishikesh is from the domestic sector.

Heavy metal is another class of pollutants responsible for many of the diseases in exposed organisms. Nickel $(\mathrm{Ni})$, copper $(\mathrm{Cu})$, Zinc $(\mathrm{Zn})$, and Lead $(\mathrm{Pb})$ were analysed in the collected water samples (Table 3). Lead was below the detection limit in all the samples. Copper was present at all the locations and ranged from 0.0321 to $0.0581 \mathrm{mg} / \mathrm{l}$ with an average value of $0.0386 \mathrm{mg} / \mathrm{l}$. Maximum concentration was reported in lower stretch. Zinc concentration varied from 0.0304 to $1.3497 \mathrm{mg} / \mathrm{l}$. The probable reason for the high concentration could be addition from some anthropogenic source. Nickel ranged from 0.0105 to $0.0367 \mathrm{mg} / \mathrm{l}$. The immediately higher values at location \#18 might be a result of wastewater added by a channel downstream of Triveni Ghat. The desirable limit as per BIS is 0.05 and $5.0 \mathrm{mg} / \mathrm{l}$ for Copper/Nickel/Lead and Zinc, respectively. 
Table 2 Standards for drinking water (Bureau of Indian Standards (BIS) 2012; IS: 10500)

\begin{tabular}{|c|c|c|c|}
\hline $\begin{array}{l}\text { S. } \\
\text { No. }\end{array}$ & Parameter & $\begin{array}{l}\text { Acceptable } \\
\text { limit }\end{array}$ & $\begin{array}{l}\text { Permissible limit in the } \\
\text { absence of alternate source }\end{array}$ \\
\hline 1. & Colour (Hazen units) & 5 & 15 \\
\hline 2. & Odour & Agreeable & Agreeable \\
\hline 3. & $\mathrm{pH}$ value & $6.5-8.5$ & No relaxation \\
\hline 4. & Taste & Agreeable & Agreeable \\
\hline 5. & $\begin{array}{l}\text { Turbidity (NTU } \\
\text { units) }\end{array}$ & 1 & 5 \\
\hline 6. & $\begin{array}{l}\text { Total dissolved solids } \\
(\mathrm{mg} / \mathrm{l})\end{array}$ & 500 & 2000 \\
\hline 7. & Aluminium (mg/l) & 0.03 & 0.2 \\
\hline 8. & Ammonia (mg/l) & 0.5 & No relaxation \\
\hline 9. & $\begin{array}{l}\text { Anionic detergents } \\
\text { (as MBAS) (mg/l) }\end{array}$ & 0.2 & 1.0 \\
\hline 10. & Barium (as Ba) (mg/l) & 0.7 & No relaxation \\
\hline 11. & Boron (as B) (mg/l) & 0.5 & 1.0 \\
\hline 12. & Cadmium (mg/l) & 0.003 & No relaxation \\
\hline 13. & $\begin{array}{l}\text { Calcium (as Ca) } \\
(\mathrm{mg} / \mathrm{l})\end{array}$ & 75 & 200 \\
\hline 14. & $\begin{array}{l}\text { Chloramines }\left(\text { as } \mathrm{Cl}_{2}\right) \\
\quad(\mathrm{mg} / \mathrm{l})\end{array}$ & 4.0 & No relaxation \\
\hline 15. & $\begin{array}{l}\text { Chloride (as Cl) } \\
\text { (mg/l) }\end{array}$ & 250 & 1,000 \\
\hline 16. & Copper (mg/l) & 0.05 & 1.5 \\
\hline 17. & Fluoride (mg/l) & 1.0 & 1.5 \\
\hline 18. & Iron $(\mathrm{mg} / \mathrm{l})$ & 0.3 & No relaxation \\
\hline 19. & Lead (mg/l) & 0.01 & No relaxation \\
\hline 20. & Magnesium (mg/l) & 30 & 100 \\
\hline 21. & Mercury (mg/l) & 0.001 & No relaxation \\
\hline 22. & Nickel (mg/l) & 0.02 & No relaxation \\
\hline 23. & Nitrate $(\mathrm{mg} / \mathrm{l})$ & 45 & No relaxation \\
\hline 24. & $\begin{array}{l}\text { Phenolic compounds } \\
\left.\quad \text { (as } \mathrm{C}_{6} \mathrm{H}_{5} \mathrm{OH}\right)(\mathrm{mg} / \mathrm{l})\end{array}$ & 0.001 & 0.002 \\
\hline 25. & $\begin{array}{l}\text { Selenium (as Se) } \\
\quad(\mathrm{mg} / \mathrm{l})\end{array}$ & 0.01 & No relaxation \\
\hline 26. & $\begin{array}{l}\text { Sulphate }\left(\mathrm{as} \mathrm{SO}_{4}\right) \\
(\mathrm{mg} / \mathrm{l})\end{array}$ & 200 & 400 \\
\hline 27. & $\begin{array}{l}\text { Sulphide }\left(\text { as } \mathrm{H}_{2} \mathrm{~S}\right) \\
(\mathrm{mg} / \mathrm{l})\end{array}$ & 0.05 & No relaxation \\
\hline 28. & $\begin{array}{l}\text { Total alkalinity } \\
\qquad\left(\text { as } \mathrm{CaCO}_{3}\right)(\mathrm{mg} / \mathrm{l})\end{array}$ & 200 & 600 \\
\hline 29. & Total arsenic $(\mathrm{mg} / \mathrm{l})$ & 0.01 & No relaxation \\
\hline 30. & Total chromium & 0.05 & No relaxation \\
\hline 31. & $\begin{array}{l}\text { Total hardness } \\
\left.\text { (as } \mathrm{CaCO}_{3}\right)(\mathrm{mg} / \mathrm{l})\end{array}$ & 200 & 600 \\
\hline 32. & Zinc $(\mathrm{mg} / \mathrm{l})$ & 5.0 & 15.0 \\
\hline 33. & Aldrin/Dieldrin $(\mu \mathrm{g} / \mathrm{l})$ & 0.03 & No relaxation \\
\hline 34. & Chlorpyriphos $(\mu \mathrm{g} / \mathrm{l})$ & 30 & No relaxation \\
\hline 35. & $2,4-\mathrm{D}(\mu \mathrm{g} / \mathrm{l})$ & 30 & No relaxation \\
\hline 36. & DDT $(\mu \mathrm{g} / \mathrm{l})$ & 1.0 & No relaxation \\
\hline 37. & Endosulfan $(\mu \mathrm{g} / \mathrm{l})$ & 0.4 & No relaxation \\
\hline
\end{tabular}

Table 2 continued

\begin{tabular}{llll}
\hline $\begin{array}{l}\text { S. } \\
\text { No. }\end{array}$ & $\begin{array}{l}\text { Parameter } \\
\text { limit }\end{array}$ & $\begin{array}{l}\text { Permissible limit in the } \\
\text { absence of alternate source }\end{array}$ \\
\hline $\begin{array}{l}\text { 38. } \\
\begin{array}{c}\text { Radioactive } \alpha \\
\text { emitters }(\mathrm{Bq} / \mathrm{l})\end{array}\end{array}$ & 0.1 & No relaxation \\
$\begin{array}{c}\text { 39. } \\
\text { Radioactive } \beta \\
\text { emitters }(\mathrm{Bq} / \mathrm{l})\end{array}$ & 1.0 & No relaxation \\
$\begin{array}{c}\text { 40. } \\
\text { Total Coliform } \\
\text { bacteria }\end{array}$ & $\begin{array}{c}\text { Shall not be detectable in any } 100 \mathrm{ml} \\
\text { sample }\end{array}$ \\
\hline
\end{tabular}

As per the Designated Best Use (DBU) classification (CPCB 2008), the water of River Ganga is suitable for drinking but after disinfection (Class A) in upper segment (location \#1-7); is suitable for organized outdoor bathing (Class B) in middle segment (location \# 8-10); and can be used as a drinking water source (Class $\mathrm{C}$ ) in lower segment (location \#11-20).

\section{Suitability for irrigation}

The criteria of suitability for drinking water, water for industrial purposes, and for agriculture are different. Therefore, water which is not fit for drinking and industrial uses may be suitable for irrigation. The suitability of waters for a specific purpose depends on the types and amounts of dissolved salts. Some of the dissolved salts or other constituents may be useful for crops. However, the suitability for irrigation is assessed in terms of the presence of undesirable constituents, and only in limited situations is irrigation water assessed as a source of plant nutrients (FAO 2008).

The most important characteristics that determine the quality of irrigation water are: $\mathrm{pH}$; total concentration of soluble salts assessed through EC; Relative proportion of $\mathrm{Na}$ to other cations such as $\mathrm{Ca}$ and $\mathrm{Mg}$, referred to as the sodium adsorption ratio (SAR); concentration of Boron and other elements that may be toxic to plants; concentration of carbonates and bicarbonates as related to the concentration of $\mathrm{Ca}$ and $\mathrm{Mg}$, referred to as residual sodium carbonate (RSC); content of anions such as chloride, sulphate and nitrate. The analytical data on the above parameters are used to describe the quality of irrigation water taking standards fixed for each aspect as an index (FAO 2008). The parameters evaluated to determine the quality for irrigation are presented in Table 4. The statistical analysis of the results obtained was done on SPSS 7.5 statistical package. The suitability of the samples was analysed on the basis of results obtained and indices evaluated; comparing the obtained values with the classification as suggested by different authors (Table 5). 
Table 3 Concentration of heavy metals in water of River Ganga in Rishikesh

\begin{tabular}{|c|c|c|c|c|}
\hline S. No. & $\mathrm{Ni}$ & $\mathrm{Pb}$ & $\mathrm{Zn}$ & $\mathrm{Cu}$ \\
\hline 1 & 0.0227 & BDL & BDL & 0.0445 \\
\hline 2 & 0.0105 & BDL & 0.1489 & 0.0371 \\
\hline 3 & 0.0245 & BDL & BDL & 0.0321 \\
\hline 4 & BDL & BDL & 0.0760 & 0.0334 \\
\hline 5 & 0.0175 & BDL & 0.3526 & 0.0346 \\
\hline 6 & 0.0245 & BDL & BDL & 0.0358 \\
\hline 7 & BDL & BDL & 0.0304 & 0.0346 \\
\hline 8 & 0.0157 & BDL & 0.0365 & 0.0334 \\
\hline 9 & 0.0140 & BDL & 0.0578 & 0.0358 \\
\hline 10 & BDL & BDL & BDL & 0.0334 \\
\hline 11 & BDL & BDL & BDL & 0.0334 \\
\hline 12 & BDL & BDL & BDL & 0.0358 \\
\hline 13 & BDL & BDL & 0.0426 & 0.0383 \\
\hline 14 & 0.0367 & BDL & BDL & 0.0531 \\
\hline 15 & BDL & BDL & BDL & 0.0408 \\
\hline 16 & BDL & BDL & 0.0669 & 0.0433 \\
\hline 17 & BDL & BDL & 0.1763 & 0.0346 \\
\hline 18 & 0.0314 & BDL & 1.3497 & 0.0420 \\
\hline 19 & BDL & BDL & BDL & 0.0581 \\
\hline 20 & NA & NA & NA & NA \\
\hline
\end{tabular}

All the values expressed in $\mathrm{mg} / \mathrm{l}$

$B D L$ Below the detection limit $(0.01 \mathrm{mg} / \mathrm{l}), N A$ Not Analysed

\section{Electrical conductivity}

The concentration of total salt content in irrigation waters, estimated in terms of EC, is an important parameter for assessing the suitability of irrigation waters. Generally, all irrigation waters with an EC of less than $2250 \mu \mathrm{S} / \mathrm{cm}$ are considered suitable except in some situations, e.g. very sensitive crops and highly clayey soils of poor permeability. The ideal value is less than $750 \mu \mathrm{S} / \mathrm{cm}$ (Richards 1954). In our study, Electrical conductivity (EC) (in $\mu \mathrm{S} /$ $\mathrm{cm}$ ) varied in the range from 38 to 170 with a mean value of 85.2. All the water samples have EC below $750 \mu \mathrm{S} / \mathrm{cm}$ indicating good quality of irrigation water.

\section{Sodium adsorption ratio (SAR)}

The degree to which the irrigation water tends to enter into cation exchange reaction in soil can be indicated by the sodium adsorption ratio. Excess sodium gets adsorbed on soil particles, thus changes the soil properties and also reduces permeability (Ayers and Bronson 1975). In this study, SAR was found in the range of $0.24-0.43$. As per
Table 4 Calculated values to assess the suitability for irrigation and industrial use

\begin{tabular}{lllllllll}
\hline S. No. & RSC & SSP & SAR & $\begin{array}{l}\text { Mg } \\
\text { Hazard }\end{array}$ & KR & PI & LSI* & RSI* \\
\hline 1 & & & & & & \\
2 & -0.88 & 25.54 & 0.39 & 0.0 & 0.34 & 42 & -0.05 & 9.7 \\
3 & -1.14 & 23.64 & 0.39 & 29.9 & 0.31 & 51 & 0.21 & 9.1 \\
4 & -1.39 & 20.57 & 0.37 & 43.1 & 0.26 & 44 & -0.28 & 9.6 \\
5 & -1.30 & 21.64 & 0.38 & 37.4 & 0.28 & 46 & 0.01 & 9.2 \\
6 & -1.14 & 21.46 & 0.38 & 37.4 & 0.27 & 54 & 1.50 & 7.4 \\
7 & -1.30 & 21.65 & 0.38 & 34.8 & 0.28 & 47 & 0.83 & 8.3 \\
8 & -1.30 & 22.59 & 0.39 & 33.9 & 0.29 & 44 & -0.02 & 9.4 \\
9 & -0.97 & 24.83 & 0.39 & 19.1 & 0.33 & 58 & 0.01 & 9.1 \\
10 & -1.14 & 24.14 & 0.43 & 36.7 & 0.32 & 53 & 0.45 & 8.7 \\
11 & -3.59 & 9.32 & 0.24 & 42.1 & 0.10 & 25 & 1.00 & 7.4 \\
12 & -2.03 & 15.19 & 0.30 & 36.8 & 0.18 & 30 & 0.24 & 9.0 \\
13 & -1.31 & 21.77 & 0.39 & 38.1 & 0.28 & 49 & 0.17 & 9.0 \\
14 & -1.95 & 15.82 & 0.32 & 28.8 & 0.19 & 35 & 0.12 & 8.8 \\
15 & -2.93 & 11.81 & 0.27 & 35.1 & 0.13 & 26 & 0.21 & 8.6 \\
16 & -2.12 & 15.22 & 0.32 & 37.7 & 0.18 & 37 & 0.36 & 8.2 \\
17 & -2.12 & 15.62 & 0.33 & 43.9 & 0.19 & 35 & 0.29 & 8.7 \\
18 & -1.55 & 18.57 & 0.35 & 37.5 & 0.23 & 43 & 0.22 & 8.9 \\
19 & -1.37 & 20.91 & 0.35 & 17.9 & 0.26 & 45 & 0.04 & 9.1 \\
20 & -3.40 & 9.71 & 0.28 & 74.5 & 0.11 & 26 & 0.18 & 8.8 \\
Mean & -1.7 & 19.2 & 0.4 & 34.8 & 0.2 & 42.6 & 0.3 & 8.8 \\
\pm SD & \pm 0.8 & \pm 5.1 & \pm 0.05 & \pm 13.8 & \pm 0.08 & \pm 10.6 & \pm 0.4 & \pm 0.6 \\
\hline & & & & & & & &
\end{tabular}

Richards (1954), water with SAR $\leq 10$ is considered as of excellent quality. Figure 2 is a plot of SAR against EC for rating irrigation water in different classes which indicate the extent that the water can affect the soil in terms of salinity hazard. All the samples were found to lie in C1S1 class, i.e. low salinity and low sodium hazard class, thus excellent for irrigation purpose for almost all soils.

\section{Bicarbonate and residual sodium carbonate (RSC)}

The concentration of bicarbonates was observed to be in the range of 4.9-34.2 with mean value of $18.8 \mathrm{mg} / \mathrm{l}$. In water having a high concentration of bicarbonate, there is a tendency for calcium and magnesium to precipitate. When this happens, there is a reduction in the concentration of calcium and magnesium and a relative increase in sodium. The calcium and magnesium are precipitated as carbonates, and any residual carbonate or bicarbonate is left in solution as RSC or bicarbonate hazard. RSC remained negative for all the water samples in this study, showing that the water is of good quality for use in irrigation. 
Table 5 Classification of water quality for irrigation

\begin{tabular}{|c|c|c|c|c|c|c|c|}
\hline Quality & $\mathrm{EC}$ range & & RSC & & KR & SAR & Mg. Hazard \\
\hline Very good & $250^{\mathrm{a}}$ & $<1,000^{\mathrm{b}}$ & $<0^{\mathrm{c}}$ & $<1.25^{\mathrm{d}}$ & $<1^{\mathrm{g}}$ & $0-10^{\mathrm{e}}$ & $<50 \%^{\mathrm{f}}$ \\
\hline Good & $250-750$ & $1,000-2,000$ & $0-2.5$ & & & $10-18$ & \\
\hline Marginal & $750-2,000$ & $2,000-4,000$ & $2.5-5.0$ & $1.25-2.5$ & $1-2$ & $18-26$ & \\
\hline Poor & $2,000-3,000$ & $4,000-6,000$ & $5.0-7.5$ & $>2.5$ & $>2$ & & $>50 \%$ \\
\hline Harmful & 3,000 & $>6,000$ & $>7.5$ & & & $>26$ & \\
\hline
\end{tabular}

a Wilcox 1955; ${ }^{\mathrm{b}}$ Bhumbla and Abrol 1972; ${ }^{\mathrm{c}}$ Bishnoi et al. 1984; ${ }^{\mathrm{d}}$ Eaton 1950; ${ }^{\mathrm{e}}$ Richards $1954 ;{ }^{\mathrm{f}}$ Paliwal $1972 ;{ }^{\mathrm{g}}$ Kelly 1963

\section{Soluble sodium percentage (SSP)}

Water intended for agricultural use should have a lower concentration of sodium ions and higher concentrations of calcium and magnesium ions. This is just opposite for water in domestic use. Excessive amounts of $\mathrm{Na}^{+}$ions may cause a significant decrease in the permeability of agricultural soils receiving such irrigation water. SSP was found to be in the range of 9.71-25.54 with the mean value of 19.24. SSP values were observed to be in lower range with a non-significant effect on irrigation quality of water.

\section{Magnesium hazard}

It is widely reported that $\mathrm{Ca}$ and $\mathrm{Mg}$ do not behave identically in soil systems, and the Mg deteriorates soil structure particularly where waters are sodium dominated and highly saline. A high level of $\mathrm{Mg}$ usually promotes a higher development of exchangeable $\mathrm{Na}$ in irrigated soils (FAO 2008). Water with magnesium hazard less than 50 is suitable for irrigation (Paliwal 1972). In our study, it is observed that magnesium hazard was less than 50 in $95 \%$ of samples. Thus, it can be safely used for irrigation except the water sample taken from the location 20 , which had $\mathrm{Mg}$ hazard ratio as 74.8 .

\section{Kelly's ratio and permeability index (PI)}

The Kelley's ratio of water samples collected at all the locations or sources ranged from 0.1 to 0.34 with mean value of 0.243 , which is well below unity indicating that the water is free from sodicity hazard and can be used for irrigation purpose.

The soil permeability is affected by long-term irrigation influenced by $\mathrm{Na}^{+}, \mathrm{Ca}^{2+}, \mathrm{Mg}^{2+}$ and $\mathrm{HCO}_{3}^{-}$contents of the soil. The permeability index values indicate the suitability of water for irrigation. The Doneen's diagram plots the permeability index, calculated from the relative proportions of sodium and bicarbonate ions on one hand, and the sum of the major cations on the other hand, against the total ion content of the water in milliequivalents per litre.

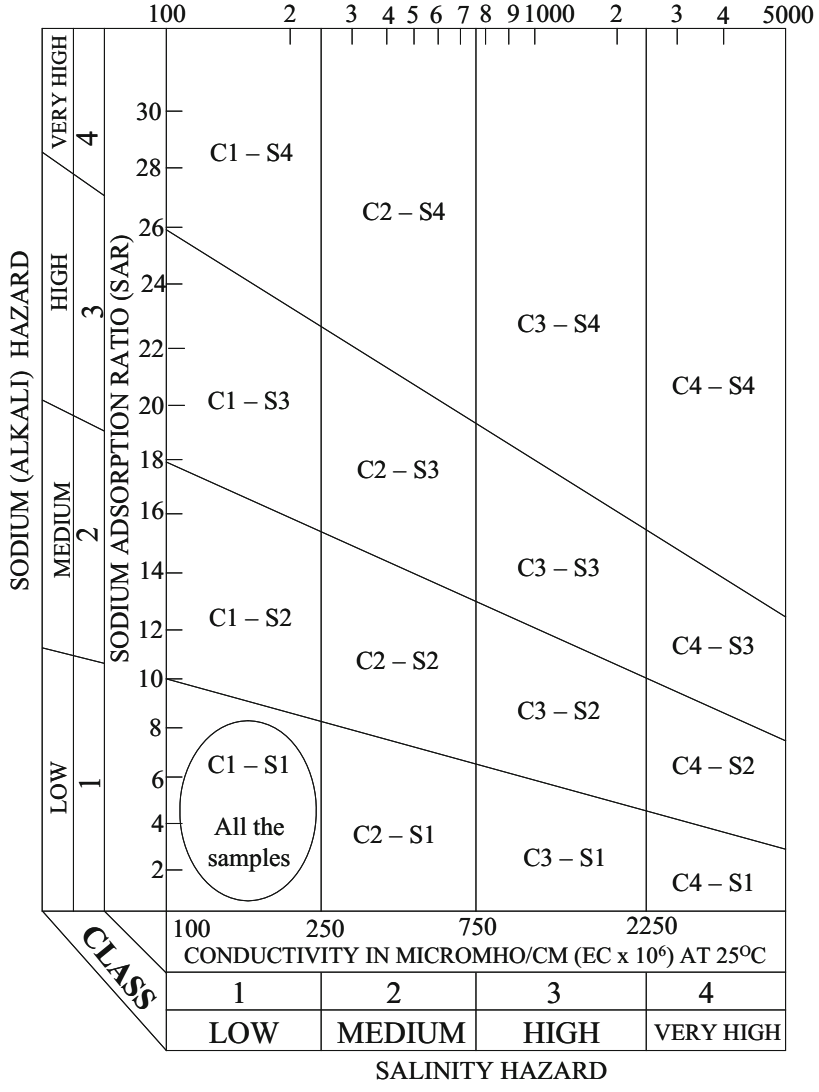

Fig. 2 Plot of calculated values of SAR and EC of water samples for classification of irrigation water (after US Salinity Laboratory Staff, 1954)

The samples of the study area fall in Class II (25-75\%) and the water of the study area is of good quality for irrigation.

\section{Chloride ion}

Chloride ion up to a concentration of $70 \mathrm{mg} / \mathrm{l}$ is considered safe. It can cause several problems in crops at concentration $>350 \mathrm{mg} / \mathrm{l}$ (Hopkins et al. 2007). In our study, the values were found in the range of 10-32.5 with a mean value of 22.1. Thus, the water from these locations/sources is within the limits and found suitable for irrigation. 
Table 6 Classification of water quality for industrial use

\begin{tabular}{llll}
\hline RSI & Inference (Ryznar 1944) & RSI & Inference (Carrier 1965) \\
\hline$<5.5$ & Heavy scale will form & $4-5$ & Heavy scale \\
& & $5-6$ & Light scale \\
$5.5-6.2$ & Scale will form & $6-7$ & Little scale or corrosion \\
$6.2-6.8$ & No difficulties & $7-7.5$ & Corrosion significant \\
$6.8-8.5$ & Water is aggressive & $7.5-9$ & Heavy corrosion \\
$>8.5$ & Water is very aggressive & $>9$ & Corrosion intolerable \\
\hline
\end{tabular}

Each of the above parameters has a bearing on the quality of irrigation water. However, each water source will have its specific suitability or hazardous nature depending on the presence (and the degree) or absence of each of the constituents. Different chemical constituents interact with one another and cause a complex effect on soil properties and plant growth. Water with a low SAR and low EC is widely suitable. However, when a value of any one of these parameters (or both) increases in its content, the water becomes less suitable for irrigation purposes. The selection of crops for such situations becomes critical. Salt-tolerant crops can be grown in such areas. Soil type is also an important consideration under such situations (FAO 2008).

\section{Suitability for industrial application}

Water for industrial use refers to applications such as cooling water, boiler feedwater, and in manufacturing processes. The water quality must be monitored to prevent pipe corrosion in utilities. For indicating the extent to which water flowing through pipes will precipitate or dissolve calcium carbonate, important factors such as Saturation Indices are used to test the quality of water. The Langelier saturation index is a calculated number used to predict the calcium carbonate stability of water. It indicates whether the water will precipitate, dissolve, or be in equilibrium with calcium carbonate. The LSI is expressed as the difference between the actual system $\mathrm{pH}$ and the saturation $\mathrm{pH}$.

$\mathrm{LSI}=\mathrm{pH}$ (measured) $-\mathrm{pHs}$ (Langlier 1936)

If the actual $\mathrm{pH}$ of the water is below the calculated saturation $\mathrm{pH}$, the LSI is negative and the water has a very limited scaling potential. If the actual $\mathrm{pH}$ exceeds $\mathrm{pHs}$, the LSI is positive, and being supersaturated with $\mathrm{CaCO}_{3}$, the water has a tendency to form scale. At increasing positive index values, the scaling potential increases. It is also worth noting that the LSI is temperature sensitive. The LSI becomes more positive as the water temperature increases. This increase in temperature can cause scaling, especially in cases such as hot water heaters. LSI was calculated for all the samples and it indicated that $85 \%$ of the samples had LSI $>0$. This indicates that the water at these sources is under saturated and will have a tendency to dissolve solid $\mathrm{CaCO}_{3}$ protective coatings in pipelines and equipment.

The Ryznar stability index (RSI) uses a database of scale thickness measurements in municipal water systems to predict the effect of water chemistry.

Ryznar saturation index (RSI) is defined as:

$\mathrm{RSI}=2 \times \mathrm{pHs}-\mathrm{pH}$ (measured)

Ryznar gives only an indication about the aggressiveness of the water but carrier gives an indication about the scale and corrosion potential of the water (Table 6). RSI values indicated that $90 \%$ water samples (RSI > 7.5) have heavy corrosion potential. $45 \%$ water samples have intolerable water potential. As per Ryznar, all the water samples taken have aggressive water, thus unsuitable for transportation through pipes.

\section{Conclusion}

During the study, it was observed that the water quality of River Ganga was good at most of the locations in Rishikesh town. The upper segment of Ganga had good quality of water to be used for drinking with minimal treatment but after disinfection. Even the concentration of heavy metals was either non-detectable or within the safe limits. The middle and lower segments had higher levels of pollutants, especially the TDS, organic matter, and MPN. Such areas may be dedicated for organized outdoor bathing for tourists and pilgrims. Night soil disposal in river bed and wastewater discharge through open channels need immediate attention to control MPN and organic load. MPN was found to be a critical parameter which needs regular monitoring and measures to control. Addition of phosphate from wastewater channels is of concern since it may lead to eutrophication particularly in the time of year when the flow is lean. The channels may be intercepted and diverted to sewage treatment plants. The water was observed to be of good to excellent quality throughout with respect to its use in irrigation for a long period of time. In industrial application, the water will not result in scale formation but may result in corrosion of pipes used for transporting the water. Such water may be used in different industrial processes with minimal pretreatment.

Acknowledgments The authors acknowledge the help of Dr. Ankur Kansal, UEPPCB, Dehradun, Uttarakhand to determine BOD and MPN; and Er. Rajesh Nain, GJUS\&T, Hisar, Haryana for his help in analysis of heavy metals. 
Open Access This article is distributed under the terms of the Creative Commons Attribution License which permits any use, distribution, and reproduction in any medium, provided the original author(s) and the source are credited.

\section{References}

Ayers RS, Bronson RL (1975) Guidelines for interpretation of water quality for agriculture. University of California, Extension Mimeographed, p 13

Bhumbla DR, Abrol IP (1972) Is your water suitable for irrigation. Indian Farming 22:15-17

Bishnoi SR, Brar SPS, Kumar D (1984) Underground water quality of Dhuri block, Distt. Sangrur, Punjab. Indian J Ecol 11(2):220-228

Bureau of Indian Standards (BIS) (2012) Indian standard drinking water specification (second revision) BIS 10500:2012, New Delhi

Carrier Air Conditioning Company (1965) Handbook of air conditioning system design. McGraw-Hill Books, New York

Central Pollution Control Board (CPCB) (2008) Guidelines for Water Quality Monitoring, MINARS/27/2007-08, New Delhi

Doneen LD (1962) The influence of crop and soil on percolating water. In: Proceedings of the 1961 Biennial conference on groundwater recharge, pp 156-163

Eaton EM (1950) Significance of carbonate in irrigation water. Soil Sci 69:123-133

Eaton AD, Clesceri LS, Greenberg AE (1995) Standard methods for the examination of water and wastewater, 19th edn. APHA, New york

FAO (2008) Guide for laboratory establishment for plant nutrient analysis. FAO, Rome

Haritash AK, Kaushik CP, Kaushik A, Kansal A, Yadav AK (2008) Suitability assessment of groundwater in some villages of Rewari district in Haryana. Environ Monit Assess 145(1-3):397-406

Hopkins BG, Horneck DA, Stevens RG, Ellsworth JW, Sullivan M (2007) Managing irrigation water quality for crops production in the Pacific Northwest. Pacific Northwest Extension Publication, Washington, p 597

Hossain F, Chang NB, Wanielista M, Xuan Z, Daranpob A (2010) Nitrification and denitrification in a passive on-site wastewater treatment system with a recirculation filtration tank. Water Qual Expo Health 2:31-46

Kaushik A, Sharma HR, Mehta B, Pragya, Shilpa, Sapna, Ishita, Veenu (2000) Groundwater quality of Ambala and Nilokheri cities in Haryana in relation land use. Environ Ecol 18(3):616-623

Kelly WP (1963) Use of saline irrigation water. Soil Sci 95:355-391

Lacy S (2006) Modeling the efficacy of the ganga action plan's restoration of the Ganga River, India. Thesis, Natural Resources and Environment, University of Michigan

Langlier WF (1936) The analytical control of anti-corrosion water treatment. J Am Water Work Assoc 28:1500-1521
Li S, Zhang Q (2010) Risk assessment and seasonal variations of dissolved trace elements and heavy metals in upper Han River, China. J Haz Mat 181:1051-1058

Li S, Xu Z, Wang H, Wang J, Zhang Q (2009) Geochemistry of upper Han River basin, China 3: anthropogenic inputs and chemical weathering to the dissolved load. Chem Geo 264:89-95

Markandya A, Murty MN (2004) Cost benefit analysis of cleaning the Ganges: some emerging environment and development issues. In: Environment and development economics, vol 9, Issue 1, Cambridge University Press, Cambridge, $\mathrm{p}$ 61-81

Mishra A, Tripathi BD (2008) Heavy metal contamination of soil, and bioaccumulation in vegetables irrigated with treated waste water in the tropical city of Varanasi, India. Toxicol and Environ Chem 90(5):861-871

National River Conservation Directorate (NRCD) (2008) Water quality monitoring for Ganga. Ministry of environment and forests, New Delhi

National River Conservation Directorate (NRCD) (2009) Status paper on River Ganga: State of Environment and Water Quality. Ministry of Environment and Forests, New Delhi

Paliwal KV (1972) Irrigation with saline water. IARI Monograph no 2 (New series), New Delhi, p 198

Rai PK, Mishra A, Tripathi BD (2010) Heavy metal and microbial pollution of River Ganga: a case study of water quality at Varanasi. Aquat Ecosyst Health Manag 13(4):352-361

Richards LA (1954) Diagnosis and improvement of saline alkali soils. In: agriculture, handbook no 60. US Department of Agriculture, Washington, p 160

Ryznar JW (1944) A new index for determining amount of calcium carbonate scale formed by water. J AWWA 36(4):472

Seth R, Singh P, Mohan M, Singh R, Aswal RS (2013) Monitoring of phenolic compounds and surfactants in water of Ganga canal, Haridwar (India). Appl Water Sci. doi:10.1007/s13201-0130116-z

Sivasubramanian P, Balasubramanian N, Soundranayagam JP, Chandrasekar N (2013) Hydrochemical characteristics of coastal aquifers of Kadaladi, Ramanathpuram District, Tamilnadu, India. Appl Water Sci 3:603-612

Srinivas Y, Oliver DH, Raj AS, Chandrasekar N (2013) Evaluation of groundwater quality in and around Nagercoil town, Tamilnadu, India: an integrated geochemical and GIS approach. Appl Water Sci 3:631-651

Trivedi RC (2010) Water quality of Ganga River-an overview. Aquat Ecosyst Health Manag 13(4):347-351

U.S. Salinity Laboratory Staff (1954) Diagnosis and improvement of saline and alkali soils. USDA, Handbook No. 60, Wasington, p 160

Vass KK, Mondal SK, Samanta SS, Suresh VR, Katiha PK (2010) The environment and fishery status of River Ganges. Aquat Ecosyst Health Manag 13(4):385-394

Wilcox LV (1955) Classification and use of irrigation water. USDA, Circular 969, Washington, DC, p 19

World Health Organization (WHO) (2006) Guidelines for drinking water quality. First addendum to third edn, vol 1, Geneva 